\title{
Environmental Management System towards Environmental Performance of Hotel Industry: Does Corporate Social Responsibility Authenticity Really Matter?
}

\author{
Zahid Yousaf ${ }^{1}$, Magdalena Radulescu ${ }^{2 *}$, Abdelmohsen A. Nassani ${ }^{3}$, Abdullah Mohammed \\ Aldakhil $^{4}$, Elena Jianu ${ }^{5}$
}

${ }^{1}$ Government College of Management Sciences

N-35, Mansehra, Khyber, Pakhtunkhwa, 21300, Pakistan

E-mail.muhammadzahid.yusuf@gmail.com

${ }^{2 *}$ Department of Finance, Accounting and Economics, University of Pitesti

Str. Targu din Vale, no.1, Pitesti, 110040, Arges Romania

E-mail.mag.radulescu@yahoo.com (Corresponding Author)

${ }^{3,4}$ Department of Management, College of Business Administration, King Saud University

P.O. 71115, Riyadh 11587, Saudi Arabia

E-mail.Nassani@ksu.edu.sa; aaldakhil@ksu.edu.sa

${ }^{5}$ Department of Management and Business Administration, University of Pitesti

Str. Targu din Vale, no.1, Pitesti, 110040, Arges Romania

E-mail.ejianu@yahoo.com

cross $^{r e f}$ http://dx.doi.org/10.5755/j01.ee.32.5.28619

Environmental Management Initiatives (EMI), as part of the sustainability management movement, have become an integrated part of the organisational management practices and of the current research. Since the implementation of Environmental Management System (EMS), there have been many studies analysing this relationship with the environmental performance. Corporate Social Responsibility (CSR) also gained a great importance for the organisations' performance, including their performance in the environmental area. However, previous studies analysed the direct link between those variables and environmental performance, while the mediating effect of those variables has not been tested yet because using a mediator in the relationship between two variables is a rather new approach in the research area used in the behavioural sciences area. This research analyses the role of EMI in defining the Environmental Performance (EP) of hotel industry, given the strong relationship between those two variables and the importance of the tourism sector for the economic development, both in the developed, but especially in the developing countries. It also investigates the CSR authenticity as mediator between EMI and EP link. Data was collected through a questionnaire of managers of the hotels in Pakistan. Correlation, Structural Equation Model and linear regressions were applied for testing the hypotheses and for checking the viability of the model. Findings revealed that EMI and CSR authenticity are important and significant determinants of EP in the hotel industry. Findings show that CSR authenticity acts as a mediator for the EMI and EP link. The stakeholder pressures and customers' environmental awareness have forced the hotel industry to implement environmental standards and this shift of focus is more important in the hotel industry. The current research demonstrates that efforts of EMI is a prerequisite for enhancing CSR authenticity in the environmental area, and this, in its turn, contributes to the increase of the EP of hotel and tourism sector in a developing country. Given the lack of large financial resources of the developing countries, this model is an important outcome for the tourism industry that helps hotels to become green, to attract more clients and to gain competitive advantages.

Keywords: CSR Authenticity, Environmental Management Initiatives, Environmental Performance, Hotel Industry, Tourism Sector.

\section{Introduction}

The increasing concern for environment protection and decreasing pollution, the growing social demands (XuanQuynh et al., 2014) or companies' interest in gaining competitive advantages (Nishitani et al., 2012) have determined the firms to adopt sustainable and environmentally responsible behaviours and to adopt ecofriendly technologies (Gonzalez-Benito et al., 2011). However, adopting this kind of technologies brings little benefit in the absence of an adequate environmental management system (EMS). Choi et al. (2019) stated that
EMS merges the environmental-related activities into the strategic organizational framework. The current study highlights the role of environment management initiatives (EMI) for the improvement of Environmental Performance (EP). This study covers an interesting phenomenon about the upcoming issue (EP) of hotel industry. Adding new insights from the live experience of hotel management, this study provides the newest idea to add Corporate Social Responsibility (CSR) authenticity in the link between EMS and EP which has not yet been explored. This is an extensive field and the topic of interest for scientific researchers, and it is related to economic issues and trends. 
This study investigates the factors affecting EP in the context of hotel businesses. The hotel businesses are the major contributors to the economic growth of any country. Various studies have analysed the EP; however, preconditions and determinates are still questioned. There are numerous environmental management initiatives (EMI) which are related to CSR authenticity. EMI is a driving force for the advancement of EP and CSR activities (Bortree, 2009). The EMI-CSR authenticity link was also studied for some industries (Bowen, 2016; Beale \& Fernando, 2009). Despite the fact that EMI has a crucial role in the organizational CSR activities, this doesn't mean that it can automatically make significant changes in EP (Pham et al., 2020). The process of implementing environmental management procedures displays great differences among the organizations, environmental-related goals or indicators are not clearly defined and environmental reporting is not mandatory (Voinea et al., 2020; Henri \& Journeault, 2008).Thus, there are mixed results regarding the impact of EMS on the EP, from no clear significant impact (Nawrocka \& Parker, 2009; Boiral et al., 2018) to a positive relation between those two variables (Claver et al., 2007; Tian \& Lin 2019; Seman et al., 2019), while some other authors found a negative relation in different industries (Barla, 2007). Hence, it is necessary to conduct a comprehensive investigation to better understand the connection between these variables, to study the EMI-EP link using a mediating variable that may enhance this relation. This new research is focusing on the mechanism that can be the reason for the advancement in CSR authenticity. We enlarge the existing knowledge about EMI and EP relation via CSR authenticity, so it makes an important addition in the existing knowledge to the hotel/tourism sector by guiding through the link between EMI, CSR authenticity and EP (Hung-Baesecke et al., 2016; Aigbedo, 2019) and by developing a new business model. When the company's actions fall short of expected social values and norms, CSR overcomes these shortages. Thus, it is important to study the EMI-EP link through CSR authenticity that can enhance EMI and EP relation in the sector of growing importance such as tourism especially for developing countries.

Tourism sector is increasingly supporting the economic growth all over the world and enables the job opportunities. Considering all this and its strong dependency on the natural resources (Han et al., 2011), its future development should be addressed in a sustainable manner in order to stay competitive and develop further (Cruz \& Soto, 2010). An extensive use of the natural resources in the tourism sector will have negative impact on tourism demand in the future (Gonzalez \& Leon, 2001). The link between the environmental management related actions and the overall performance of the companies is stronger for the sectors that are customer-oriented, just like the tourism sector, because of their environmental reputation impact on their business (Tilt, 1997).

The hospitality sector has a significant interest in protecting the environment because nice and safe surroundings are good for business. The growing interest in the research in the environmental policies and practices area applied in the hotel and hospitality industry as hospitality organizations are eager to know how a firm's EMS could be appropriately implemented after the launch of Agenda 21
(Eric et al., 2016). Hotel managers realized that implementing the environmental management practices can bring them a growing number of customers with "high green awareness" (Kim et al., 2017; Chou, 2014). However, the environmental management research was not conducted merely for the hotel and hospitality sector if we consider the EP assessment (Chen \& Hsieh, 2011). It is necessary to see the corporations' variables that can enhance directly or indirectly the EP of companies.

Chan (2009) has studied the EMI as EMS-related research issues. The study of EMS is significant as ISO 14001 expressing their commitment to protect the environment to gain many advantages, from financial benefits to marketing benefits (Eric et al., 2016). Hotel managers can reduce costs and pollution, but can also settle a tighter relation with customers and other stakeholders based on loyalty and legitimacy due to their environmental-related concerns, which gives them a differentiation competitive advantage that differs from one sector to another (Sharma et al., 2007). Chen and Hsieh (2011) proved in their study of the hotel industry that as star rating goes up, hotels consume large resources and negatively impact the environment. Hence, the managers of hotels should involve all the stakeholders (employees, customers, authorities) in their efforts to implement EMS and to adopt EMI.

Responsible business is a necessary condition of the environmental protection. Many organizations all over the world are involved in CSR-related activities in order to reach a competitive advantage and to succeed in the long-run (Porter \& Kramer, 2011). Businesses have focus on CSR for increasing their productivity, but also reduce the waste of resources and environmental pollution (Mazurkiewicz, 2004). Previous studies have shown that consumers appreciate organizations that are involved in CSR with loyalty and trust (Madrigal \& Boush, 2008) and those that are perceived as applying CSR for public-serving and altruistic reasons (Ellen et al., 2006). That is why, some organizations are successful in applying CSR, while others are not (Alhouti et al., 2016). It is necessary to add CSR as an integral part of business strategies to attain competitiveness in current tourism and hotel industry (Joo et al., 2019). The stakeholders' pressure to save the environment has put pressure on all types of organizations to take part in CSR activities to fulfil environmental, economic and social duties for enhancing the corporate EP (Joo et al., 2019; Singh et al., 2019). Rodriguez and del Mar Armas Cruz (2007) investigated the link between corporate social environmental responsibility and performance in hotels and demonstrated a positive link.

Various studies have analysed the EP; however, preconditions and determinants are still questioned. There are numerous environment management initiatives (EMI) which are related to CSR authenticity. EMI is a driving force for the advancement of EP and CSR activities (Bortree, 2009). The link between EMI and CSR authenticity was also studied for some industries (Bowen, 2016; Beale \& Fernando, 2009). Despite the fact that EMI has a crucial role for the organizational CSR activities, this doesn't mean that it can automatically make significant changes in EP (Pham et al., 2020). The process of implementing the environmental management procedures displays great differences among the organizations, environmental-related goals or indicators are 
not clearly defined and environmental reporting is not mandatory (Voinea et al., 2020; Henri \& Journeault, 2008). Thus, there are mixed results regarding the impact of EMS on the EP, from no clear significant impact (Nawrocka \& Parker, 2009; Boiral et al., 2018) to a positive relation between those two variables (Claver et al., 2007; Tian \& Lin 2019; Seman et al., 2019), while some other authors found a negative relation in different industries (Barla, 2007). There are both quantitative (Kassinis \& Vafeas, 2006) or qualitative studies (based on surveys) that aimed to analyse the EP of the companies (Phan \& Baird, 2015). In the qualitative studies, the results were very mixed (Boiral et al., 2018). These mixed or contradictory results on this linkage give the opportunity for deeper research. The studies are difficult to compare because they use different measurement for EP outcome and analyse different economic areas. Moreover, EMI are seen as voluntary actions undertaken by the organizations in order to protect the environment. Therefore, the stakeholders' perceptions of the authenticity of such initiatives and the reason behind them or behind the organizations' involvement in the CSRrelated activities needs to be considered on the way of achieving EP. As we have stated above, there are previous studies that proved the direct and positive relation between the variables included in this study, but we have used a relatively new approach in the empirical research, by analysing the mediating/indirect effect of CSR-authenticity on the EMI-EP link to check if this variable enhances the positive effect of EMI on EP.

So, it is necessary to conduct a comprehensive investigation to better understand the connection between these variables, to study the EMI-EP link using a mediating variable that may enhance this relation. This new research is focusing on the mechanism that can be the reason for the advancement of CSR authenticity. EMI positively improve EP through CSR authenticity i.e. initiated through EMI, (Aigbedo, 2019). When the company's actions fall short of the expected social values and norms, CSR overcomes these shortages. Thus, CSR authenticity as mediator in EMI-EP link is an important achievement of this study for tourism sector in developing countries context.

Next sections are arranged as follows: first, we have presented literature, then, we have presented the methodology we have applied for this research and then results have been summarized. In the last section limitations and future research are presented.

\section{Literature Review}

Environmental Management Initiatives and Environmental Performance

EMI is depicted as ecological asset preservation endeavours, natural approach and preparing and ecological public connection endeavours (Jia \& Chen, 2019). In this manner, EMI is a significant function for developing of EP (Tironi \& FarIas, 2015). EMI implies both an efficient implementation, but also the support granted for achieving EP (Nawroka \& Parker, 2009). It is a major tool for addressing and actively managing the environmental issues (Voinea et al., 2020). A simple implementation of EMS doesn't necessarily lead to the improvement of the EP of an organization. Some researchers claimed it is a superficial tool used to improve only the stakeholders' perception but without truly improving the environmental efficiency (Boiral, 2007).

EP is characterized by Corsini (2019) as how much an organization is making a move to fuse ecological contemplations in its operational choices and observing the adequate principles, personal circumstance and reacts to partners (Ren et al., 2020). There is an increasing worry among all partners about ecological issues related with items, producing cycle, bundling, and conveyance (Golgeci et al., 2019). This is one of the significant main thrusts for organizations to incorporate natural issues as a significant component of vital administration, and along these lines, begun thinking about EP as a significant part of their general presentation (Lam et al., 2016). Ceaseless improvement of EP builds the piece of the pie, help companies to continue with the current clients and convince new expected clients.

EP refers to all those activities which are initiated to clean environment from all aspects. EP enable firms to utilize resources, save energy and water capability, minimize pollution through the extended reuse and reusing, and the abatement of dangerous waste and unsafe defilements (Garcia Martin \& Herrero, 2020; Memon et al., 2020). Quantitative methods to measure organizations' EP are not yet defined and can be analyse quantitatively or qualitatively and may be based on questionnaires (Phan \& Baird, 2015).

EMS implementation and EMI has been studied by some several studies, that highlighted the improvement effect of the relationships with stakeholders (Boiral et al., 2018) and an improvement of the EP (Tourais \& Videira, 2016; Voinea et al., 2020).

For other sectors (manufacturing one), the link is much weaker or it couldn't have been proved (Hertin et al., 2008). Previous studies analysing EMS didn't show a negative or a positive correlation of the EMS with the EP (Boiral et al., 2018; Hertin et al., 2008), and these mixed or contradictory results opens the new corridors of future topics (Voinea \& Fratostiteanu, 2018). Previous researchers use different measurement for EP outcome and analyse different sectors. Daddi et al. (2011) found for Italian firms from 6 different economic sectors that implementing EMS leads to EP improvements only in some cases.

Managers in the tourism industry can use this research outcome to elaborate the organizations' EMS in order to achieve EP.

Iraldoet al. (2009) have demonstrated a positive impact of the EMS on the EP while some other studies have proved that EMI represents a major managerial tool for the environment protection (Molina-Azorin et al., 2015; Hsiao et al., 2014). Studies that considered a set of quantitative environmental indicators shows EP is outcome of EMS. If some quantitative environmental indicators (waste prevention or energy consumption) are selected, most of studies have found their significant improvement after the implementation of EMS, compared to the firms not having implemented EMS. But, if these indicators are considered in a general way (and less quantitative), the significance of EMS on EP becomes less significant (Voinea et al., 2020). 
At hierarchical level, EMI have clearly demonstrated a significant commitment for the improvement of EP (Wiengarten \& Pagell, 2012). As per others, when organizations are committed towards the assurance of indigenous habitat, the degree of EP of those organizations consequently improves, and they are in a superior situation to design administrative approaches and address institutional requests (Al-Sheyadi et al., 2019). Likewise, when organizations are more disposed towards EMI to grow favourable to ecological items, it is created according to rules and guidelines, during assembling measure, misuse of material and contamination is controlled, and item is planned as recyclable (Aigbedo, 2019). Along these lines, EMI prompts improved EP. The purpose for business to include in the natural assurance systems is to pick up supportability by accomplishing seriousness and biological upgrade. In this manner, the prime worry of EMI is the means by which organization is participating in a manner that is agreeable to business to improve EP (O'Riordan \& Rayner, 1991). The EMS can promote innovation and because of that the organizations can achieve EP in the same time with the overall organizational performance (Melnyk et al., 2003; Florida \& Davison, 2001). Implementing green innovative technologies can help organizations to achieve EP and overall performance (Klassen \& Whybark, 1999).

As all the above statements have given enough proof that EMI upholds the business to pick up EP, we can thus build up the following hypothesis:

H1 EMI and EP are positively associated and EMI positively impact on EP

Environmental Management Initiatives and CSR Authenticity

CSR authenticity is characterized as the dependability, truthfulness and validity of an organization's CSR exercises seen by its partner, regardless of whether an organization is seen to be genuinely socially mindful and occupied with CSR rehearses (van Rekom \& Calter, 2014). In many recent years, pondering on the subject of EM increases wide consideration of CSR specialists. EMI has the compelling capacity to shape the ability and choices to include in CSR related exercises and assurance of indigenous habitat (Golgeci et al., 2019).

The degree of EMI impact on the way that partners judge an organization's contribution in CSR related activities is still debatable (Wei et al., 2018). EMI represents an important factor for promoting CSR-related activities (Hur et al., 2019), but it is not sufficient enough for the way that stakeholders perceive CSR-related activities as being authentic (Lin et al., 2020). CSR authenticity is strongly and positively related to the environmental management strategies and initiatives as Lin et al. (2020) have demonstrated in their study for the tourism and hotel industry. Lower level of EMI contributes to the restriction of the perspectives and to a negative view of partners towards CSR exercises of an association, while a company that implements an EMS receives more attention of stakeholder's for strengthening CSR authenticity (Choi et al., 2019; Heinze et al., 2014). An organization with natural asset protection endeavours, ecological arrangement and preparing and ecological public connection endeavours acquire consideration of partner's and society. Subsequently, a feeling of higher CSR authenticity is produced. EMI positively influence the involvement of organizations in CSR related activities and in adopting an environmental and eco-friendly behaviour. An organization displaying an environmental policy and environmental efforts benefits of a higher attention of all the stakeholder's for improving its CSR authenticity (Choi et al., 2019). Stakeholders appreciate those organizations which are involved in green environmental actions to authenticate CSR actions in their operational activities. Lower level of EMI implies an unfavourable perception of stakeholders about the involvement of the organization into the CSRrelated activities (Yoon \& Lee, 2016). Therefore, we state the following hypothesis:

H2 EMI and CSR Authenticity are positively associated and EMI positively impact on CRS Authenticity

\section{CSR Authenticity and Environmental Performance}

CSR is evergreen topic of contemporary research in business sectors (Andrei et al., 2014). United Nation's Global Compact underlined that, being sustainable, corporates are inclined towards CSR efforts. Many researchers emphasized the convergence between those two concepts. Cheng et al. (2014) described CSR as integrating social initiatives in the corporate operations and Bansal et al. (2014) proved that CSR is committed to both social welfare activities and also improving environmental practices. Some authors even merged CSR with the idea of corporate sustainability, since both cover economic, social, and environmental dimensions (Hahn et al., 2018; Nikolaou et al., 2019). Bansal and Song (2017) have elaborated an extensive analysis about the connection between CSR and sustainability. Responsibility and sustainability research use similar definitions, assumptions, and measurement, so that their differences have been lost.

Ahmad et al. (2021) proved in their study on the service sector of Pakistan, that CSR initiatives directly and indirectly (through employees' pro-environmental behaviour) impact on the EP of the organizations.

Companies can increase their overall performance by implementing CSR-related activities in the environmental protection area, but this depends on their available resources, management capabilities, the economic domain and specific regulations; companies should target sustainability aim by cutting their costs and decreasing the environmental risks, and by improving their relation with consumers by promoting a eco-friendly image (Fijalkowska et al., 2018).By establishing an adequate institutional frameworks and regulations that support responsible business, the governments can significantly determine CSR adoption (Zhang et al., 2019)

Currently, researchers are analysing CSR activities because customers prefer goods and services that are ecofriendly (Kraus et al., 2020). Organizations had to deal with the pressure from organizations' stakeholders to present their social and environmental issues (Pekovic \& Vogt, 2021). Previous authors paid little attention to CSR to measure the EP so far (Orazalin, 2020), although many 
studies proved the positive relation between CSR and economic performance (Hernandez et al., 2020).

CSR authenticity alludes to those impressions of partners and society which are identified with the organizations' activities identified with the CSR exercises for shielding climate from decay brought about by business exercises (Alhouti et al., 2016). CSR authenticity is a critical indicator for increasing the EP (Joo et al., 2019). Contribution of an organization for the security of indigenous habitat advances CSR genuineness which is considered as a powerful method to build organization's EP (Tian \& Lin, 2019). The supposition that CSR authenticity is a critical indicator of hierarchical EP is perceived as the company's interest in natural exercises far beyond their employment prerequisites prepares so that the organization can support its ecological effectiveness (Olthuis \& van den Oever, 2020). Since CSR authenticity comprises of partner's positive recognition with respect to CSR activities, it is consistent to contend that partner's observation decidedly influences organization's EP.

There are endless motivations to contend why EP can be improved with the support of CSR authenticity. From the survey of the previous studies written with respect to the ecological execution, various models can be cited as we have stated above. Therefore, we may state that through certain impression of society and partners with respect to CSR activities, CSR authenticity may improve EP:

H3 CSR Authenticity and EP are positively associated and CSR Authenticity positively impacts on EP

\section{CSR Authenticity as Mediator}

The present research underlines the mediating role of CSR authenticity for the EMI and EP link. As we have presented above, the organizations' CSR-related initiatives are very important for their EP. However, this does not mean that EMI are enough for the well-being of the society and natural environment protection. There is necessary to consider the organization CSR authenticity that might be involved in this relationship. CSR authenticity is represented by the perception of stakeholders regarding sincerity of a company's CSR initiatives, and it shows if an organization is perceived to be truly socially responsible and engaged in CSR practices because a higher level of stakeholder's perception regarding CSR activities supports the companies' efforts to protect the environment (AlShammari et al., 2019). CSR initiatives related to environment and society well-being supports the increase of the EP of a company (Sloot et al., 2018).

Thus, the present research uses the CSR authenticity in order to investigate the relationship between EMI and EP. The model we have built is focused on logic that links 'how environmental initiatives (EMI) are developed', 'to what extent stakeholder perceived (CSR authenticity)', and 'how organization can achieve EP'. CSR authenticity 'what stakeholder perceived' relies on the organization's EMI that supports stakeholders' view regarding authenticity in CSRrelated activities and that improves EP of the organizations (O'Connor \& Keil, 2017; Phillips et al., 2019).

CSR authenticity acts as a link between EMI and EP because EMI supports the implementation of CSR-related activities and those, in turn, support the achievement of EP (Seroka-Stolka, 2016). Thus, EMI and CSR-related initiatives increase the perception of a higher level of CSR authenticity, which in turn supports the final goal of raising the EP (Rhou \& Singal, 2020; Hur et al., 2019).

Some authors proved that EMI build employees' attitudes and behaviours, and, therefore positively impact on the EP of the organizations (Chen \& Tung, 2014; MolinaAzorin et al., 2015). Many previous studies on hotels EMI analysed the consumers' perceptions of hotels' environmental efforts and their intentions for involving in CSR-related activities (Chen \& Tung, 2014).

The issues concerning environmental protection are very complex and focus on economic, social and political matters and involve different categories of stakeholders (Panait \& Petrescu, 2015). This is why CSR-related activities are important for achieving the EP and CSR authenticity is strongly and positively related to the EMI (Lin et al., 2020).

The current investigation features the intervening function of CSR authenticity in the relationship between EMI-CSR authenticity-EP. As we talked about before that organization's activity with respect to CSR is essential for their CSR authenticity and EP of an organization, notwithstanding, this doesn't imply that EMI are separated from everyone else adequate for the advancement of society and regular habitat (Ma et al., 2020; Shim et al., 2017). There in a desperate need to consider the association CSR authenticity that may be engaged with this relationship. Clearly CSR authenticity being an impression of partners in regards to reliability, earnestness and validity of an organization's CSR activities, regardless of whether an organization is seen to be genuinely socially capable and occupied with CSR rehearses, in light of the fact that with more elevated level of partner's discernment with respect to CSR exercises help the association for the advancement of authenticity and climate. Association's activities identifying with climate and society prosperity gives establishment to the advancement of CSR authenticity and EP (Bauman \& Skitka, 2012).

Along these lines, the current investigation is focused on the CSR credibility to clarify the connection among EMI and CSR authenticity and EP. The theoretical model fixated on rationale that joins 'how natural activities restricting association (EMI) are created, 'how much partner apparent (CSR authenticity), and 'what association can accomplish (CSR authenticity and EP) (Liu et al., 2019). CSR credibility 'what partner apparent' depends on association EMI that advance partner impression of association with respect to genuineness and dependability in CSR related exercises, which is eventually improve CSR authenticity and EP of the association.

CSR credibility goes about as a scaffold among EMI and CSR authenticity and EP, on the grounds that EMI tie association for the execution of CSR related exercises, which empower the association to advance CSR authenticity and EP (Lauritzen, 1994). Subsequently, CSR related activities which give premise to CSR credibility, which thusly upgrades CSR authenticity and EP. Besides, analysts emphasized that EMI upgrades partner convictions with respect to association ecological administration endeavours and activities, prompting elevated level of CSR authenticity. 
H4 CSR Authenticity mediates the link between EMI and $E P$

The theoretical frame of this research is summarized in Figure 1.

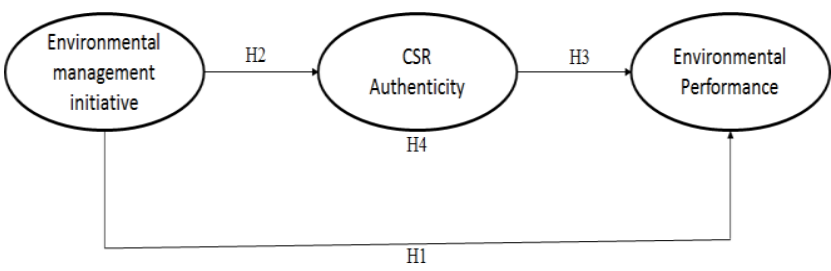

Figure 1. Theoretical Frame Work

\section{Methodology}

The present research used cross-sectional data for analysis from the list of 206 hotels. 830 managers of various 3 stars, 4 stars and 5 stars hotels were identified for data collection. Data for the study was gathered in two stages. The motives for proceeding with the survey into two different stages were to decrease participants' tension (Cooper et al., 2020; Tuan, 2019). Before collecting the full datasets, a pilot test on 35 respondents was conducted (Srinivasan \& Lohith, 2017). Questionnaire converted in both languages (Urdu and English) was checked by industry experts and academia scholars. Analysis was conducted on final useable 830 responses.

\section{Measurement}

5-point Likert scale was used and questionnaire consist two sections. First, the specific features of hotels regarding age and size, and education and experience of managers were mentioned, using those variables as control. The second section items details of variables used in research.
EMI

The scale of EMI was adapted from Choi et al., (2019) and also used for empirical study by Lin et al., (2020) and it consists of 32 items (see Appendix). The major dimensions of EMI include: Policies/Training about environment, efforts for resource conservation, and public-relation efforts (Choi et al., 2019).

\section{CSR authenticity}

CSR authenticity scale was adapted from Lin et al. (2020) and it consists of 8 items (see Appendix).

\section{Environmental performance}

A 15 items scale for EP was adapted from the study of Anser et al., (2020) and it has 4 major dimensions (resource usage, stakeholder interaction, regulatory compliance, and productivity) (see Appendix).

\section{Analysis and Results}

The result of correlation shows that independent and dependent variables are positively related to each other. Then we check the causality effect between IV (Independent Variable) and DV (Dependent Variable) using regression. Hence our study utilized both correlation and causality approaches for analysis purpose. Those two methods are applied together (Majid et al., 2019; Lin et al., 2020; Anser et al., 2020). To check linear-relationships a covariance approach is used to conclude directional relation among variables (Williams \& Brown, 1994). Consistent with the procedures of the existing empirical studies (Gadenne et al., 2009; Leonidou et al., 2015) and Majid et al., 2019), we employed various statistical packages for data analysis. This study has used CFA to confirm data is fitted to the developed model. SEM was used to ensure the model fitness and the relations among variables used in this study.

\section{Reliability and Validity}

SEM technique was applied for confirmatory factor analysis (CFA). Discriminant validity of the research model was settled with the support of CFA technique (Table 1).

Table 1

Validity Tests

\begin{tabular}{llllll}
\hline & Items & Alpha & FL & CR & AVE \\
\hline EMI & 32 & 0.88 & $0.82-0.87$ & 0.93 & 0.74 \\
CSR Authenticity & 8 & 0.86 & $0.81-0.88$ & 0.95 & 0.76 \\
Environmental Performance & 15 & 0.84 & $0.81-0.87$ & 0.96 & 0.78 \\
\hline
\end{tabular}

Table 2 shows Model fitness through CFA. The results were satisfactory $\left(\chi^{2}=934.26 ; d f=399 \mathrm{p}<.001\right.$; CFI $=.92$; $\mathrm{GFI}=.93$ and $\mathrm{RMESA}=.043)$.

Table 2

Results of CFA

\begin{tabular}{llllll}
\hline Model & $\boldsymbol{\chi 2}$ & Df & $\boldsymbol{\chi 2}$ df & RMESA & GFI \\
\hline Hypothesized three-factor model & 934.26 & 399 & 2.342 & 0.043 & 0.93 \\
Two-factor model & 1096.56 & 301 & 3.643 & 0.92 & 0.87 \\
Single-factor model & 1196.87 & 375 & 3.192 & 0.84 & 0.24 \\
\hline
\end{tabular}




\section{Descriptive Statistics}

Results of Mean, SD and correlation are presented in Table no 3. Results proved correlations among the study constructs at significant level. EMI and CSR authenticity has significant correlation $(\mathrm{r}=.39)$. EMI and EP has significant correlation $(r=.20)$. CSR authenticity and EP has significant correlation $(\mathrm{r}=.38)$. Business age and business size (as control variables) show a positive correlation which is quite normal. Business age is also positively correlated with EMI, while respondent education is positively correlated with CSR authenticity (Table 3).

Table 3

Results of Correlations

\begin{tabular}{|c|c|c|c|c|c|c|c|c|c|}
\hline Variable & Mean & SD & 1 & 2 & 3 & 4 & 5 & 6 & 7 \\
\hline $1 \quad$ Business age & 1.22 & 0.41 & 1.00 & & & & & & \\
\hline business size & 1.41 & 0.52 & $.142 * *$ & 1.00 & & & & & \\
\hline Respondent education & 3.89 & 0.65 & -0.016 & 0.026 & 1.00 & & & & \\
\hline $4 \quad$ Respondent experience & 2.21 & 0.62 & 0.065 & 0.040 & -0.18 & 1.00 & & & \\
\hline $\begin{array}{l}5 \text { Environmental management } \\
\text { initiative }\end{array}$ & 3.66 & 0.49 & $.074 *$ & -0.022 & -0.01 & -0.15 & 1.00 & & \\
\hline CSR Authenticity & 3.44 & 0.63 & -0.065 & 0.066 & $.083 *$ & -0.15 & $.391 * *$ & 1.00 & \\
\hline $7 \quad$ Environmental Performance & 3.42 & 0.64 & -0.12 & -0.02 & -0.07 & -0.05 & $.201 * *$ & $.381 * *$ & 1.00 \\
\hline
\end{tabular}

\section{Hypothesis Testing}

Table 4 shows the hypothesis testing of direct effects of variables. Simple linear regression was used of this research. The results of hypothesis show that all paths were significant and positively associated with each other (See
Table 4). EMI is positively and significantly predicting EP $\left(\mathrm{B}=0.20^{* *}, \mathrm{p}<0.0001\right), \mathrm{H} 1$ is accepted. EMI

is positively and significantly linked with CSR authenticity $\left(\mathrm{B}=0.38^{* *}, \mathrm{p}<0.0001\right), \mathrm{H} 2$ is accepted. CSR authenticity is positively and significantly connected with $\mathrm{EP}\left(\mathrm{B}=0.40^{* *}, \mathrm{p}<0.0001\right), \mathrm{H} 3$ is accepted.

Table 4

Results of Hypothesis of $\mathrm{H1}, \mathrm{H} 2$ \& $\mathrm{H3}$

\begin{tabular}{lllllll}
\hline Model & Details & Beta & T & F & Sig & Remarks \\
\hline 1 & EMI $\rightarrow$ EP & 0.20 & 11.82 & 34.88 & 0.000 & H1-Proved \\
2 & EMI $\rightarrow$ CSR authenticity & 0.38 & 16.54 & 140.64 & 0.000 & H2-Proved \\
3 & CSR $\rightarrow$ EP & 0.40 & 11.85 & 56.98 & 0.000 & H3- Proved \\
\hline
\end{tabular}

Table 5 shows the mediating role of CSR authenticity between EMI and EP. To conduct mediation test we followed the study of Preacher and Hayes (2008) approach. The mediating role is validated with significant value of indirect effect. Results proves that CSR authenticity acts as mediator between EMI and EP. (Beta $=0.21$, lower value $=$ 0.1555 , Upper value $=0.2945)$. We also used soble test analysis " $\mathrm{Z}$ score" and results proved that $\mathrm{z}$ score $=7.832 * *$ value was significant. Hence H6 was accepted.

Results of Indirect Effect Mediator as CSR Authenticity

\begin{tabular}{|c|c|c|c|c|c|c|}
\hline Model Detail & Data & Boot & Bias & SE & Lower & Upper \\
\hline $\begin{array}{l}\mathrm{EMI} \rightarrow \mathrm{CSR} \text { authen } \rightarrow \mathrm{EP} \\
\text { Soble Test } Z \text { Score }=7.8326\end{array}$ & 0.2153 & & -0.002 & 0.335 & 0.1555 & 0.2945 \\
\hline
\end{tabular}

Results of testing the hypothesis are shown in Figure 2.

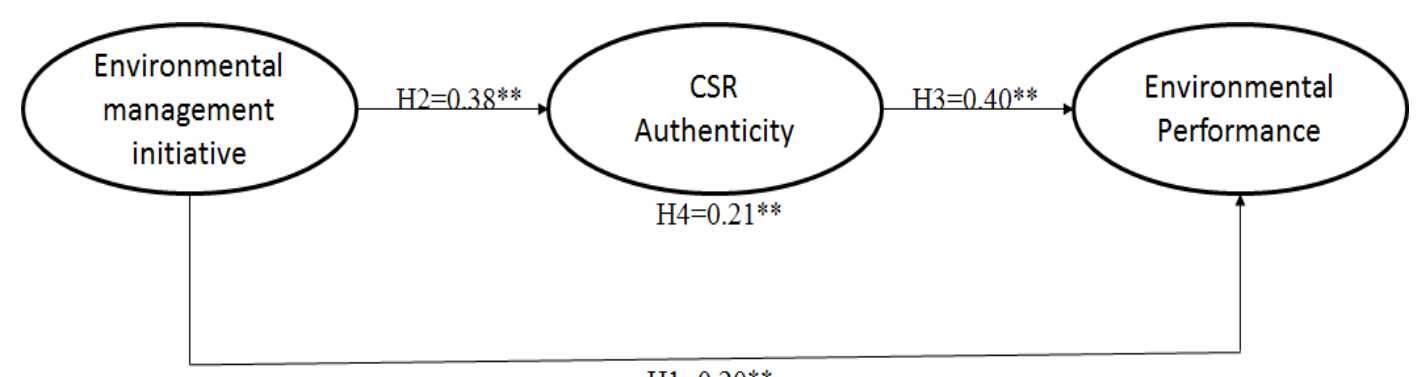

$\mathrm{H} 1=0.20^{* *}$

Figure 2. Theoretical Frame Work 


\section{Discussion of Results}

This study was performed on the organizational level involvement in the environmental concerns regarding EMI and CSR authenticity to achieve EP. Besides this study also aim to investigate the mediating role of CSR authenticity between EMI and EP link. Correlation matrix shows a high correlation between the variables use in the analysis (EMICSR authenticity-EP) and between business age (as control variable) and business size or EMI. Four hypotheses were proposed to check the interplay among EMI, CSR authenticity and EP.

Concerning $\mathrm{H} 1$ the results of this study support that EMI of hotel and tourism industry predicts the EP and related to previous work (Molina-Azorin et al., 2015; Hsiao et al., 2014). So, EMI represent a major tool for addressing and actively managing the environmental issues (Voinea et al., 2020; Tourais \& Videira, 2016), but a simple implementation of EMI doesn't necessarily lead to the improvement of the EP of an organization. These voluntary environmental initiatives should be perceived as being authentic to enhance EP, not just for conforming to the regulations, and they should actively support innovation in this area. The EMI-EP link is stronger for the sectors that are customer-oriented, just like the tourism sector, because of their environmental reputation impact on their business (Tilt, 1997), but much weaker or not existent for other sectors (Hertin et al., 2008). Therefore, the outcome of the current study is important for the hotel industry, for achieving EP especially in a developing country which relies on this sector revenues.

Regarding $\mathrm{H} 2$, this study confirms that EMI can positively influence CSR authenticity. The results are in line with previous findings on this direct positive relationship (Hur et al., 2019; Choi et al., 2019). An organization implementing EMS and voluntary acting in the environmental area benefits of a higher attention of all the stakeholder's for improving the authenticity of their initiatives and CSR-related activities (Choi et al., 2019). Lower level of EMI leads to an unfavourable perception of stakeholders about the involvement of the organization into the CSR-related activities (Yoon \& Lee, 2016).

$\mathrm{H} 3$ proposed that CSR authenticity can determine the EP. The results of this study extended the previous work on the domain of CSR (Joo et al., 2019; Tian \& Lin, 2019) and demonstrated that CSR authenticity can predict EP.CSRrelated activities impact on the EP of the organizations (Ahmad et al., 2021).CSR authenticity is a significant indicator that prepares organization to support its ecological effectiveness (Olthuis \& van den Oever, 2020). Cheng et al. (2014) and Bansal et al. (2014) proved that CSR is committed to both social and environmental practices. Bansal and Song (2017) merged the notion of CSR with the sustainability of the organizations.

H4 shows and confirmed that CSR authenticity mediates the link between EMI and EP. CSR initiatives and activities in the environmental area that are perceived as being authentic enhance the EP of the hotel sector because tourism sector is very customer-oriented and depends on the stakeholders' perceptions more than other sectors (Sloot et al., 2018). The hotel managers should make high efforts so the stakeholders should perceive their environmental initiatives and CSR-related activities as being authentic.

\section{Conclusions - Theoretical and Practical Implications}

This research aims to investigate the interplay between the EMI and the corporate EP in the hotel industry, using CSR authenticity as mediating variable which can enhance the impact of EMI on EP. The growing importance of the tourism sector for all the economies and the increasing pressures and demands of stakeholders for authentic environmental CSR-related activities have requested such an investigation to enlarge the existing knowledge on this specific topic.

These results can provide some important policy and practical recommendations for the management of the corporations for increasing their EP. This research has major practical implications by emphasizing the role of the environmental strategies and the authenticity of the CSR environmental-related activities to improve EP of the companies. The existing research lacks to achieve any clear and strong results about the impact of environmental management strategy on the EP of the companies (Solovida and Latan, 2017; Latan et al., 2018). The study emphasized the role of an organizational mediator (CSR authenticity) for achieving EP. Using a mediator between exogenous variables and the dependent variables represents a new approach in the analyses and that is why this study significantly contributes to the existing literature. The important contribution is at managerial level because it underlines the way the CSR authenticity impact on the organization performance in the environmental area. The important role of the environmental initiatives and the role of the authenticity of CSR for organizations' performance was demonstrated by some recent studies (Choi et al., 2019; Lee \& Yoon, 2018; Yoon \& Lee, 2016), but this study elevates the existing knowledge by using the authenticity of CSR as mediator in the relationship between EMI and the EP (dependent variable) as the major aim of the current research. CFA shows a good fit of this model. Correlation analysis shows a strong and significant correlation between these three variables. All the designed hypotheses were tested and validated by using linear regression. The mediating effect of CSR authenticity was also validated using bootstrapping method. The stakeholders' perceptions about hotels involvement in CSR-related activities and the perceptions about the authentic motives behind this involvement enhance the EMS adoption in the organization frame and its effect on EP achievement.

This research elevates and extends the existing knowledge by providing an empiric model for the hospitality and tourism industry. Given the major role of the tourism industry for the economic growth and development of the economies all over the world, this model is an important outcome. This empiric model analyses the impact of the EMI and CSR authenticity on the EP in the hotel and tourism sector. The relation between the EMI, CSR authenticity and EP of the companies was scarcely analysed in the existing literature. The current research demonstrates that efforts of EMI is a prerequisite for enhancing CSR authenticity in the environmental area, and this, in its turn, 
contributes to the increase of the EP of hotel and tourism sector. There is a positive correlation among those variables and a positive causality between EMI and CSR authenticity, among EMI and EP and among CSR authenticity and EP. This is an important outcome for the hotel and tourism sectors because Pakistan is becoming an important tourism destination. It shows how the hotel and tourism industries can achieve EP through EMI and the authenticity of CSRrelated activities enlarging the findings on some previous studies in this field. This model can be a very important managerial tool for hotels' managers because it helps them to better understand the relation between the EMI, the authenticity of CSR and the EP. The hotel managers should focus more on these inter-correlations for their strategic aims in the environmental area. This way, they can achieve a long-term sustainable EP for their corporations and they can gain strong competitive advantages on this specific market which is continuously growing.

Pakistan is developing more and more its tourisms and hospitality sector which is a positive sign for the hoteliers because there is expected a high influx of tourists. The managers of hotel sector should focus more on their customers' needs, which generates customers' loyalty and thus, the rise of the achieved income (Kazmi \& Shah, 2020).

This research analyses the mediating role of CSR authenticity between the EMI-EP link, but other organizational variables can be studied as mediators for enhancing this relationship. Other direction for further research would be to apply this analysis in other sectors, with different specific features, such as manufacturing industries or for SMEs that represent the major part of the Pakistani economy.

This study also presents some limitations which might be interesting future guidelines. Further studies should consider a qualitative approach and there should be episodic interviews. These interviews should be conducted during the peak business time to check whether businesses are applying environmental practices. The other major limitation of this study is that it didn't use moderating variables. The next study should include moderating variable between EMS and EP to check how this link is strengthened.

\section{Acknowledgement}

Researchers Supporting Project number (RSP-2021/87), King Saud University, Riyadh, Saudi Arabia.

\section{Appendix-Questionnaire}

1. Environmental Management Initiatives (adapted from Lin et al., 2020)

\section{Environmental resource conservation efforts}

1. My hotel always uses automatic lighting controls (e.g., daylighting sensors and timers).

2. Our hotel always resets room temperatures after guests depart.

3. Most of the equipment and products that my hotel uses are energy efficient.

4. Most of the lighting installed in my hotel are energy efficient.

5. My hotel effectively uses an energy consumption monitoring system.

6. My hotel installs water-efficient devices and equipment (e.g. low-flow shower heads).

7. My hotel uses alternative water sources (e.g. grey water or collected rainwater) for certain applications (e.g. toilet flushing or landscape irrigation).

8. My hotel utilizes well its metering equipment to track water usage.

9. My hotel tries to compost organic food waste.

10. My hotel uses refillable amenity dispensers.

11. My hotel performs a suitable disposal/treatment/storage of waste.

12. My hotel regularly purchases recycled-content products.

13. My hotel makes recycling bins available in offices and guest rooms.

14. My hotel avoids using disposal items (e.g., disposable tableware).

\section{Environmental policy and training}

15. Our hotel's environmental policies are successfully implemented under its management systems.

16. Our hotel has clear goals (short, medium, and long term) regarding its environmental policies.

17. Our hotel incorporates environmental management into its corporate policy.

18. Our hotel's environmental policies meet current environmental regulations (i.e., wastewater discharge).

19. Our hotel appoints professional environmental managers, and they regularly check the hotel's progress andrecord its system implementation.

20. Our hotel employees fully understand the extent of the hotel's environmental policies.

21. Our hotel always monitors employees' environmental management performance.

22. Our hotel provides frequent environmental education workshops.

23. Our hotel fosters environmental communication between its staff and the managers at the establishment.

24. Our hotel implements well employee environmental training programs.

\section{Environmental public relation efforts}

25. Our hotel cooperates with non-governmental organizations to enhance its environmental management.

26. Our hotel pursues environmental certifications (e.g. LEED, Green Seal, Green Key, and ISO14000).

27. Our hotel supports local communities to enhance the local environment. 
28. Our hotel takes the lead in providing activities that raise environment awareness.

29. Our hotel endeavors to educate guests on environmental issues related to the geographic area (e.g.localhabitats and conservation).

30. Our hotel provides guests with various opportunities to participate in recycling and re-utilizing.

31. Our hotel displays various signs reminding guests to save environmental resources.

32. Our hotel systematically assesses guests' complaints and suggestions to improve environmental practices.

2. CSR Authenticity (adapted from Choi et al., 2019)

1. Our hotel's CSR actions are genuine.

2. The CSR action preserves what our hotel's means.

3. The CSR action captures what makes our hotel's unique.

4. Our hotel's CSR action is in accordance with the its valuesand beliefs.

5. Our hotel is being true to itself with its CSR actions.

6. Our hotel's is standing up for what it believes in.

7. Our hotel's is a socially responsible company.

8. Our hotel's is concerned about improving the well-being of society.

3. Environmental Performance (adapted from Anser et al., 2020)

1. My hotel improved environmental performance through the reduction in material costs

2. My hotel improved environmental performance through thereduction in process/production costs

3. My hotel improved environmental performance through thereduction in costs of regulatory compliance

4. My hotel improved environmental performance through theincreased process/production efficiency

5. My hotel improved environmental performance through theincreased in productivity

6. My hotel improved environmental performance through theincreased knowledge about effective ways of managing operations

7. My hotel improved environmental performance through theimproved process innovations

8. My hotel improved environmental performance through the improved product quality

9. My hotel improved environmental performance through the improved product innovations

10. My hotel improved environmental performance through theorganizational-wide learning among employees about environmental issues

11. We have better relationships with stakeholders such as local communities, regulators, and environmental groups

12. We have improved employee morale on about environmental issues

13. Overall improved company reputation or goodwill

14. My hotel improved environmental performance through filters and controls on emissions and discharges

15. My hotel improved environmental performance through residue recycling

\section{References}

Aigbedo, H. (2019). Assessment of the effect of location and financial variables on environmental management performance for industrial goods supply chains. Journal of environmental management, 236, 2C54-268. https://doi.org/10.10 16/j.jenvman.2018.11.066

Alhouti, S., Johnson, C. M., \& Holloway, B. B. (2016). Corporate social responsibility authenticity: Investigating its antecedents and outcomes. Journal of Business Research, 69(3), 1242-1249. https://doi.org/10.1016/j.jbusres.2015.09.007

Al-Shammari, M., Rasheed, A., \& Al-Shammari, H. A. (2019). CEO narcissism and corporate social responsibility: Does CEO narcissism affect CSR focus? Journal of Business Research, 104, 106-117. https://doi.org/10.1016/j.jbusres.2019.07.005

Al-Sheyadi, A., Muyldermans, L., \& Kauppi, K. (2019). The complementarity of green supply chain management practices and the impact on environmental performance. Journal of environmental management, 242, $186-198$. https://doi.org/10.1016/j.jenvman.2019.04.078

Andrei, J. V. Panait, M., \& Voica, C. (2014). Implication of the CSR and cultural model features in Romanian energy sector, Industrija, 42(4), 115-131. https://doi.org/10.5937/industrija42-7236

Anser, M. K., Yousaf, Z., Majid, A., \& Yasir, M. (2020). Does corporate social responsibility commitment and participation predict environmental and social performance? Corporate Social Responsibility and Environmental Management, 27(6), 2578-2587. https://doi.org/10.1002/csr.1977

Bansal, P., \& Song, H. C. (2017). Similar but not the same: differentiating corporate sustainability from corporate responsibility, Academy of Management Annals, 11(1), 105-149. https://doi.org/10.5465/annals.2015.0095

Bansal, P., Gao, J., \& Qureshi, I. (2014). The extensiveness of corporate social and environmental commitment across firms over time. Organization Studies, 35, 949-966. https://doi.org/10.1177/0170840613515564 
Barla, P. (2007) ISO 14001 certification and environmental performance in Quebec's pulp and paper industry, Journal of Environmental Economics and Management, 53, 291-306. https://doi.org/10.1016/j.jeem.2006.10.004

Bauman, C. W., \& Skitka, L. J. (2012). Corporate social responsibility as a source of employee satisfaction. Research in Organizational Behaviour, 32, 63-86. https://doi.org/10.1016/j.riob.2012.11.002

Beale, F., \& Fernando, M. (2009). Short-termism and genuineness in environmental initiatives: a comparative case study of two oil companies. European Management Journal, 27(1), 26-35. https://doi.org/10.1016/j.emj.2008.05.002

Boiral, O., Guillaumie, L., Saizarbitoria, I. H., \& Tene, C. V. T. (2018) Adoption and outcomes of ISO 14001: A systematic review. International Journal of Management Reviews, 20, 411-432. https://doi.org/10.1111/ijmr.12139

Boiral, O. (2007). Corporate greening through ISO 14001: A rational myth? Organisational Science, 18, $127-146$. https://doi.org/10.1287/orsc.1060.0224

Bortree, D. S. (2009). The impact of green initiatives on environmental legitimacy and admiration of the organization. Public Relations Review, 35(2), 133-135. https://doi.org/10.1016/j.pubrev.2009.01.002

Bowen, S. A. (2016). Clarifying ethics terms in public relations from A to V, authenticity to virtue: Bled Com special issue of PR review sleeping (with the) media: Media relations. Public Relations Review, 42(4), 564-572. https://doi.org/10.1016/j.pubrev.2016.03.012

Chen, H. S., \& Hsieh, T. (2011). An environmental performance assessment of the hotel industry using an ecological footprint, International Journal of Hospitality Management,2(1), 1-11.

Chen, M. F., \& Tung, P. J. (2014) Developing an extended Theory of Planned Behaviour model to predict consumers' intention to visit green hotels, International Journal of Hospitality Management, 36, 221-230. https://doi.org/10.10 16/j.ijhm.2013.09.006

Cheng, B., Ioannou, I., \& Serafeim, G. (2014). Corporate social responsibility and access to finance. Strategic Management Journal, 35, 1-23. https://doi.org/10.1002/smj.2131

Choi, H. M., Kim, W. G., Kim, Y. J., \& Agmapisarn, C. (2019). Hotel environmental management initiative (HEMI) scale development. International Journal of Hospitality Management, 77, 562-572. https://doi.org/10.1016/j.ijhm.2018.08.020

Chou, C. J. (2014). Hotels' environmental policies and employee personal environmental beliefs: interactions and outcomes, Tourism Management, 40, 436-446. https://doi.org/10.1016/j.tourman.2013.08.001

Claver, E., Lopez, M. D., Molina, J. F., \& Tari, J. J. (2007). Environmental management and firm performance: a case study, Journal of Environmental Management, 84(4), 606-619. https://doi.org/10.1016/j.jenvman.2006.09.012

Cooper, B., Eva, N., Fazlelahi, F. Z., Newman, A., Lee, A., \& Obschonka, M. (2020). Common method variance in vocational behaviour research: Reviewing the state of the literature. Journal of Vocational Behaviour, 103472. https://doi.org/10.1016/j.jvb.2020.103472

Corsini, F., Appio, F. P., \& Frey, M. (2019). Exploring the antecedents and consequences of environmental performance in micro-enterprises: The case of the Italian craft beer industry. Technological Forecasting and Social Change, 138, 340350. https://doi.org/10.1016/j.techfore.2018.10.018

Cruz, Y. A., \& Soto, E. G. (2010). Research model of the environmental management in hotel firms, Revista de Turismo et Patrimonio Cultural, 8(4), 479-492. https://doi.org/10.25145/j.pasos.2010.08.042

Daddi, T., Magistrelli, M., Frey, M., \& Iraldo, F. (2011). Do environmental management systems improve environmental performance? Empirical evidence from Italian companies. Environment, Development and Sustainability, 13(5), 845-862. https://doi.org/10.1007/s10668-011-9294-8

Ellen, P. S., Webb, D. J., \& Mohr, L. A. (2006). Building corporate associations: Consumer attributions for corporate socially responsible programs. Journal of the Academy of Marketing Science, 34(2), 147-157. https://doi.org/10.1 177/0092070305284976

Eric, S. W., Chan, C., \& Hsu, H. C. (2016). Environmental management research in hospitality, International Journal of Contemporary Hospitality Management, 28(5), 886-923. https://doi.org/10.1108/IJCHM-02-2015-0076

Fijalkowska, J., Zyznarska-Dworczak, B., \& Garsztka, P. (2018). Corporate social-environmental performance versus financial performance of banks in central and eastern European countries. Sustainability, 10, 772. https://doi.org/10.33 90/su10030772

Florida, R., \& Davison, D. (2001). Gaining from green management: Environmental management systems inside and outside the factory. California Management Review, 43, 64-84. https://doi.org/10.2307/41166089

Gadenne, D. L., Kennedy, J., \& McKeiver, C. (2009). An empirical study of environmental awareness and practices in SMEs. Journal of Business Ethics, 84, 45-63. https://doi.org/10.1007/s10551-008-9672-9

Garcia Martin, C. J., \& Herrero, B. (2020). Do board characteristics affect environmental performance? A study of EU firms. Corporate Social Responsibility and Environmental Management, 27(1), 74-94. https://doi.org/10.1002/csr.1775

Gonzalez, M., \& Leon, C. (2001). The adoption of environmental innovations in the hotel industry of Gran Canaria, Tourism Economics, 7(2), 177-190. https://doi.org/10.5367/000000001101297801 
Gonzalez-Benito, J., Lannelongue, G., \& Queiruga, D. (2011). Stakeholders and environmental management systems: A synergistic influence on environmental imbalance, Journal of Cleaner Production, 19(14), 1622-1630. https://doi.org/10.1016/j.jclepro.2011.05.013

Golgeci, I., Gligor, D. M., Tatoglu, E., \& Arda, O. A. (2019). A relational view of environmental performance: What role do environmental collaboration and cross-functional alignment play? Journal of Business Research,96, 35-46. https://doi.org/10.1016/j.jbusres.2018.10.058

Hahn, T., Figge, F., Pinkse, J., \& Preuss, L. A. (2018). Paradox Perspective on Corporate Sustainability: Descriptive, Instrumental, and Normative Aspects. Journal of Business Ethics, 148, 235-248. https://doi.org/10.1007/s10551-017$3587-2$

Han, H., Hsu, L. T., Lee, J. S., \& Sheu, C. (2011). Are lodging customers ready to go green? An examination of attitudes, demographics, and eco-friendly intentions, International Journal of Hospitality Management, 30, $345-355$. https://doi.org/10.1016/j.ijhm.2010.07.008

Heinze, K. L., Soderstrom, S., \& Zdroik, J. (2014). Toward strategic and authentic corporate social responsibility in professional sport: A case study of the Detroit Lions, Journal of Sport Management, 28(6), 672-686. https://doi.org/10.112 3/JSM.2013-0307

Henri, J. F., \& Journeault, M. (2008). Environmental performance indicators: an empirical study of Canadian manufacturing firms, Journal of Environmental Management, 87, 165-176. https://doi.org/10.1016/j.jenvman.2007.01.009

Hertin, J., Berkhout, F., \& Wagner, M. (2008). Tyteca, D. Are EMS environmentally effective? The link between environmental management systems and environmental performance in European companies. Journal of Environmental Planning Management, 51, 259-283. https://doi.org/10.1080/09640560701865040

Hsiao, T. Y., Chuang, C. M., Kuo, N. W., \& Yu, S. M. F. (2014). Establishing attributes of an environmental management system for green hotel evaluation. International Journal of Hospitality Management, 36, 197-208. https://doi.org/10.10 16/j.ijhm.2013.09.005

Hur, W. M., Moon, T. W., \& Choi, W. H. (2019). When are internal and external corporate social responsibility initiatives amplified? Employee engagement in corporate social responsibility initiatives on prosocial and proactive behaviours, Corporate Social Responsibility and Environmental Management, 26(4), 849-858. https://doi.org/10.1002/csr.1725

Iraldo, F., Testa, F., \& Frey, M. (2009). Is an environmental management system able to influence environmental and competitive performance? The case of the eco-management and audit scheme (EMAS) in the European union. Journal of Cleaner Production,17, 1444-1452. https://doi.org/10.1016/j.jclepro.2009.05.013

Jia, K., \& Chen, S. (2019). Could campaign-style enforcement improve environmental performance? Evidence from China's central environmental protection inspection. Journal of environmental management, 245, 282-290. https://doi.org/10.101 6/j.jenvman.2019.05.114

Joo, S., Miller, E. G., \& Fink, J. S. (2019). Consumer evaluations of CSR authenticity: Development and validation of a multidimensional CSR authenticity scale. Journal of Business Research,98, 236-249. https://doi.org/10.1016/ j.jbusres.2019.01.060

Kassinis, G. I., \& Vafeas, N. (2006). Stakeholder pressures and environmental performance. Academy of Management Journal, 49, 145-159. https://doi.org/10.5465/amj.2006.20785799

Kazmi, M., \& Shah, S. A. H. (2020). Six Sigma, a Road to Infallible Service Quality in Hotel Industry of Pakistan. Artech Journal of Tourism Research \& Hospitality, 1, 6-12.

Kim, W.G., Li, J., Justin, Han, J. S., \& Kim, Y. (2017). The influence of recent hotel amenities and green practices on guests' price premium and revisit intention, Tourism Economics, 23, 577-593. https://doi.org/10.5367/te.2015.0531

Klassen, R. D., \& Whybark, D. C. (1999). The impact of environmental technologies on manufacturing performance. Academy Management Journal, 42, 599-615. https://doi.org/10.2307/256982

Kraus, S., Rehman, S. U., \& Garcia, F. J. S. (2020). Corporate social responsibility and environmental performance: The mediating role of environmental strategy and green innovation. Technological Forecasting and Social Change, 160, 120262. https://doi.org/10.1016/j.techfore.2020.120262

Lam, H. K., Yeung, A. C., Cheng, T. C. E., \& Humphreys, P. K. (2016). Corporate environmental initiatives in the Chinese context: Performance implications and contextual factors. International Journal of Production Economics, 180, 48-56. https://doi.org/10.1016/j.ijpe.2016.06.020

Latan, H., Jabbour, C. J. C., de Sousa Jabbour, A. B. L, Wamba, S. F., \& Shahbaz, M. (2018). Effects of environmental strategy, environmental uncertainty and top management's commitment on corporate environmental performance: The role of environmental management accounting. Journal of Cleaner Production, 180, 297-306. https://doi.org/10.1016/ j.jclepro.2018.01.106

Lauritzen, E. K. (1994). Environmental management in large construction projects. In Studies in Environmental Science, 60, 727-736. https://doi.org/10.1016/S0166-1116(08)71505-X 
Lee, S., \& Yoon, J. (2018). Does the authenticity of corporate social responsibility affect employee commitment? Social Behaviour and Personality: An International Journal, 46(4), 617-632. https://doi.org/10.2224/sbp.6475

Leonidou, L. C., Fotiadis, T. A., Christodoulides, P., Spyropoulou, S., \& Katsikeas, C. S. (2015) Environmentally friendly export business strategy: Its determinants and effects on competitive advantage and performance. International Business Review, 24, 798-811. https://doi.org/10.1016/j.ibusrev.2015.02.001

Lin, K., Peng, M., Anser M.K., Yousaf, Z., \& Sharif, A. (2020) Bright harmony of environmental management initiatives for achieving corporate social responsibility authenticity and legitimacy: Glimpse of hotel and tourism industry, Corporate Social Responsibility and Environmental Management, 1-8, https://doi.org/10.1002/csr.2076

Liu, Y., Li, J., Quan, B. T., \& Yang, J. B. (2019). Decision analysis and coordination of two-stage supply chain considering cost information asymmetry of corporate social responsibility. Journal of Cleaner Production, 228, 1073-1087. https://doi.org/10.1016/j.jclepro.2019.04.247

Ma, Y., Zhang, Q., \& Yin, H. (2020). Environmental management and labour productivity: The moderating role of quality management. Journal of environmental management, 255, 109795. https://doi.org/10.1016/j.jenvman.2019.109795

Madrigal, R., \& Boush, D. M. (2008). Social responsibility as a unique dimension of brand personality and consumers' willingness to reward, Psychology and Marketing, 25(6), 538-564. https://doi.org/10.1002/mar.20224

Majid A, Yasir M., Yasir M., \& Javed A. (2019). Nexus of institutional pressures, environmentally friendly business strategies, and environmental performance. Corporate Social Responsibility and Environmental Management, 27(2), 706-716. https://doi.org/10.1002/csr.1837

Mazurkiewicz, P. (2004). Corporate environmental responsibility: Is a common CSR framework possible. Working Paper 42183, World Bank: Washington, DC, USA.

Melnyk, S. A.; Sroufe, R., \& Calantone, R. J. (2003). Assessing the impact of environmental management systems on corporate and environmental performance, Journal of Operational Management, 21, 329-351. https://doi.org/10.1016/S02726963(02)00109-2

Memon, A., Yong An, Z., \& Memon, M. Q. (2020). Does financial availability sustain financial, innovative, and environmental performance? Relation via opportunity recognition, Corporate social responsibility and environmental management, 27(2), 562-575. https://doi.org/10.1002/csr.1820

Molina-Azorin, J. F., Tari, J. J., Pereira-Moliner, J., Lopez-Gamero, M. D., \& Pertusa-Ortega, E. M. (2015). The effects of quality and environmental management on competitive advantage: a mixed methods study in the hotel industry. Tourism Management, 50, 41-54. https://doi.org/10.1016/j.tourman.2015.01.008

Nawrocka, D., \& Parker, T. J. (2009) Finding the connection: Environmental management systems and environmental performance. Journal of Cleaner Production, 17, 601-607. https://doi.org/10.1016/j.jclepro.2008.10.003

Nikolaou, I. E., Tsalis, T. A., \& Evangelinos, K. I. (2019). A framework to measure corporate sustainability performance: A strong sustainability-based view of firm. Sustainable Production and Consumption, 18, 1-18. https://doi.org/10. 1016/j.spc.2018.10.004

Nishitani, K., Kaneko, S., Fujii, H., \& Komatsu S. (2012). Are firms' voluntary environmental management activities beneficial for the environment and business? An empirical study focusing on Japanese manufacturing firms, Journal of Environmental Management, 105, 121-130. https://doi.org/10.1016/j.jenvman.2012.03.054

O'Connor, J., \& Keil, M. (2017). The effects of construal level and small wins framing on an individual's commitment to an environmental initiative. Journal of environmental psychology, 52, 1-10. https://doi.org/10.1016/j.jenvp.2017.04.010

Olthuis, B. R., \& van den Oever, K. F. (2020). The board of directors and CSR: How does ideological diversity on the board impact CSR? Journal of Cleaner Production, 251, 119532. https://doi.org/10.1016/j.jclepro.2019.119532

O'Riordan, T., \& Rayner, S. (1991) Risk management for global environmental change. Global Environmental Change, 1(2), 91-108. https://doi.org/10.1016/0959-3780(91)90017-N

Orazalin, N. (2020). Do board sustainability committees contribute to corporate environmental and social performance? The mediating role of corporate social responsibility strategy. Business Strategy and the Environment, 29(1), $140-153$. https://doi.org/10.1002/bse.2354

Panait, M., \& Petrescu, M. G. (2015). Quality management and social responsibility in the context of sustainable development, Industrija, 43(4), 175-189. https://doi.org/10.5937/industrija43-8981

Pekovic, S., \& Vogt, S. (2021). The fit between corporate social responsibility and corporate governance: the impact on a firm's financial performance. Review of Management and Science, 15, 1095-1125. https://doi.org/10.1007/s11846-020-00389-x

Pham, N. T., Thanh, T. V., Tuckova, Z., \& Thuy, V. T. N. (2020). The role of green human resource management in driving hotel's environmental performance: Interaction and mediation analysis. International Journal of Hospitality Management, 88, 102392. https://doi.org/10.1016/j.ijhm.2019.102392

Phan, T. N., \& Baird, K. (2015). The comprehensiveness of environmental management systems: The influence of institutional pressures and the impact on environmental performance. Journal of Environmental Management, 160, 45-56. https://doi.org/10.1016/j.jenvman.2015.06.006 
Phillips, S., Thai, V. V., \& Halim, Z. (2019). Airline Value Chain Capabilities and CSR Performance: The Connection Between CSR Leadership and CSR Culture with CSR Performance, Customer Satisfaction and Financial Performance. The Asian Journal of Shipping and Logistics, 35(1), 30-40. https://doi.org/10.1016/j.ajsl.2019.03.005

Porter, M. E., \& Kramer, M. R. (2011). Creating shared value, Harvard Business Review, 89, 62-77.

Preacher, K. J., \& Hayes, A. F. (2008). Asymptotic and resampling strategies for assessing and comparing indirect effects in multiple mediator models. Behaviour Research Methods, 40(3), 879-891. https://doi.org/10.3758/BRM.40.3.879

Ren, S., Wei, W., Sun, H., Xu, Q., Hu, Y., \& Chen, X. (2020). Can mandatory environmental information disclosure achieve a win-win for a firm's environmental and economic performance? Journal of Cleaner Production, 250, 119530. https://doi.org/10.1016/j.jclepro.2019.119530

Rhou, Y., \& Singal, M. (2020). A review of the business case for CSR in the hospitality industry. International Journal of Hospitality Management, 84, 102330. https://doi.org/10.1016/j.ijhm.2019.102330

Rodriguez, F. J. G., \& del Mar Armas Cruz, Y. (2007) Relation between social-environmental responsibility and performance in hotel firms, International Journal of Hospitality Management, 26(4), 824-839. https://doi.org/10.1016/ j.ijhm.2006.08.003

Seman, N. A. A., Govindan, K., Mardani, A., Zakuan, N., Saman, M. Z. M., Hooker, R. E., \& Ozkul, S. (2019). The mediating effect of green innovation on the relationship between green supply chain management and environmental performance. Journal of Cleaner production, 229, 115-127. https://doi.org/10.1016/j.jclepro.2019.03.211

Seroka-Stolka, O. (2016). Green initiatives in environmental management of logistics companies. Transportation Research Procedia, 16, 483-489. https://doi.org/10.1016/j.trpro.2016.11.045

Sharma, S., Arago'n-Correa, J. A., \& Rueda-Manzanares, A. (2007). The contingent influence of organizational capabilities on proactive environmental strategy in the service sector: an analysis of North American and European ski resorts, Canadian Journal of Administrative Sciences, 24, 268-283. https://doi.org/10.1002/cjas.35

Shim, K., Chung, M., \& Kim, Y. (2017) Does ethical orientation matter? Determinants of public reaction to CSR communication. Public Relations Review, 43(4), 817-828. https://doi.org/10.1016/j.pubrev.2017.05.001

Singh, S. K., Chen, J., Del Giudice, M., \& El-Kassar, A. N. (2019). Environmental ethics, environmental performance, and competitive advantage: role of environmental training. Technological Forecasting and Social Change, 146, $203-211$. https://doi.org/10.1016/j.techfore.2019.05.032

Sloot, D., Jans, L., \& Steg, L. (2018). Can community energy initiatives motivate sustainable energy behaviours? The role of initiative involvement and personal pro-environmental motivation. Journal of Environmental Psychology, 57, 99-106. https://doi.org/10.1016/j.jenvp.2018.06.007

Solovida, G. T., \& Latan, H. (2017). Linking environmental strategy to environmental performance: Mediation role of environmental management accounting, Sustainability Accounting, Management and Policy Journal, 8(5), 595-619. https://doi.org/10.1108/SAMPJ-08-2016-0046

Srinivasan R., \& Lohith C. P. (2017). Pilot Study-Assessment of Validity and Reliability. In: Strategic Marketing and Innovation for Indian MSMEs. India Studies in Business and Economics. Springer, Singapore. https://doi.org/10.1007/978-981-10-3590-6_6

Tian, P., \& Lin, B. (2019). Impact of financing constraints on firm's environmental performance: Evidence from China with survey data. Journal of Cleaner Production, 217, 432-439. https://doi.org/10.1016/j.jclepro.2019.01.209

Tilt, C. A. (1997) Environmental policies of major companies: Australian evidence. British Accounting Review, $29,367-394$. https://doi.org/10.1006/bare.1996.0048

Tironi, M., \& Farias, I. (2015). Building a park, immunising life: Environmental management and radical asymmetry. Geoforum, 66, 167-175. https://doi.org/10.1016/j.geoforum.2015.05.001

Tourais, P. C., \& Videira, N. (2016). Why, how and what do organizations achieve with the implementation of environmental management Systems? Lessons from a comprehensive review on the eco-management and audit scheme. Sustainability, 8, 283, 1-25, https://doi.org/10.3390/su8030283

Tuan, L. T. (2019). Catalyzing Employee OCBE in Tour Companies: Charismatic Leadership, Organizational Justice, and Pro Environmental Behaviours. Journal of Hospitality \& Tourism Research, 43, 682-711. https://doi.org/10.11 $77 / 1096348018817582$

van Rekom, J., Go, F. M., \& Calter, D. M. (2014). Communicating a company's positive impact on society-Can plausible explanations secure authenticity? Journal of Business Research,67(9), 1831-1838. https://doi.org/10.101 6/j.jbusres.2013.12.006

Voinea, C. L., Hoogenberg, B. J., Fratostiteanu, C., \& Bin Azam Hashmi, H. (2020). The Relation between Environmental Management Systems and Environmental and Financial Performance in Emerging Economies, Sustainability, 12(13), 5309. https://doi.org/10.3390/su12135309

Voinea, C. L., \& Fratostiteanu, C. (2018). Corporate Social in Emerging Economies: Reality and Illusion; Routledge: New York, NY, USA. https://doi.org/10.4324/9781315112411 
Wei, W., Kim, G., Miao, L., Behnke, C., \& Almanza, B. (2018). Consumer inferences of corporate social responsibility (CSR) claims on packaged foods. Journal of Business Research, 83, 186-201. https://doi.org/10.1016/j.jbusres.2017.10.046

Wiengarten, F., \& Pagell, M. (2012). The importance of quality management for the success of environmental management initiatives. International Journal of Production Economics, 140(1), 407-415. https://doi.org/10.1016/j.ijpe.2012.06.024

Williams, L. J., \& Brown, B. K., (1994). Method variance in organizational behavior and human resources research: Effects on correlations, path coefficients, and hypothesis testing. Organizational Behavior and Human Decision Process, 57, 185-209. https://doi.org/10.1006/obhd.1994.1011

Xuan-Quynh, L. E., Van-Hieu, V. U., Hens, L., \& Heur, B. V. (2014). Stakeholder perceptions and involvement in the implementation of EMS in ports in Vietnam and Cambodia, Journal of Cleaner Production, 64, $173-193$. https://doi.org/10.1016/j.jclepro.2013.07.032

Yoon, J., \& Lee, S. (2016). What makes employees zealous supporters of their firm's CSR initiative? The role of employees' perceptions of their firm's CSR authenticity. Advances in Group Processes, 33, 93-126. https://doi.org/10.1108/S0882614520160000033004

Zhang, Q., Oo, B. L., \& Lim, B. T. H. (2019). Drivers, motivations, and barriers to the implementation of corporate social responsibility practices by construction enterprises: A review. Journal of Cleaner Production, 201,563-584. https://doi.org/10.1016/j.jclepro.2018.11.050

\section{Authors' Biographies}

Zahid Yousaf is an Assistant Professor in Government College of Management Sciences, Abbottabad-Pakistan. He is the author of more than 35 publications in different Peer-reviewed \& SSCI research journals. His work has been published in Journal of Organizational Change Management, International Journal of Contemporary and Hospitality Management, Journal of Cleaner Production, Environmental Science and Pollution Research, European Journal of Innovation Management, Eurasian Business Review, Management Decision, Environmental Research, Corporate Social Responsibility and Environmental Management, etc. He has presented various research papers at different international conferences.

Magdalena Radulescu is a Full Professor Habilitated at the Department of Finance, Accounting and Economics, University of Pitesti, Str. Targu din Vale, no.1, Pitesti, Arges Romania. She is the Scientific Coordinator for Ph.D. Students at University "Lucian Blaga" of Sibiu in the Economics. She has published many papers in the Environmental area in Sustainability, Energies, Resources Policy, Environmental Science and Pollution Research, Economic Research, Statistika journals. She is the Editor at Energies journal. She is a guest editor at Energies, Journal of Risk and Financial Management Journal, Frontiers in Environmental Science. She acts as a reviewer for Frontiers journals, MDPI journals, Wiley, Taylor\&Francis, and Springer journals. Her research interests include Energy Policy, Renewable Energy, Environmental Tax, Carbon Neutrality.

Abdelmohsen A. Nassani is a Full Professor at the Department of Management, College of Business Administration, King Saud University, Saudi Arabia. He is a Doctor of Business Administration. His research interests include Environmental Sciences, Business Management, Performance Management, and he published many papers in top journals in those fields.

Abdullah Mohammed Aldakhil is a Full Professor at the Department of Management, College of Business Administration, King Saud University, Saudi Arabia. He is a Doctor of Business Administration. His research interests include Natural Resources Management, Sustainable Development, Business Management, Supply Chain, and he published many papers in top journals in those fields.

Elena Jianu is an Associate Professor at the Department of Management and Business Administration, University of Pitesti, Romania. She is a doctor in Management. Her research interests include Supply Chain Management, Sustainable Development, CSR. She published papers in many international journals indexed in international databases.

The article has been reviewed. Received in March 2021; accepted in December 2021.

This article is an Open Access article distributed under the terms and conditions of the Creative Commons Attribution 4.0 (CC BY 4.0) License (http://creativecommons.org/licenses/by/4.0/). 